\title{
Genetic introgression of farmed salmon in native populations: quantifying the relative influence of population size and frequency of escapees
}

\author{
Mikko Heino $^{1,2, *}$, Terje Svåsand ${ }^{2}$, Vidar Wennevik ${ }^{2}$, Kevin A. Glover ${ }^{2}$ \\ ${ }^{1}$ Department of Biology, University of Beren, Box 7803, 5020 Bergen, Norway \\ ${ }^{2}$ Institute of Marine Research, PO Box 1870 Nordnes, 5817 Bergen, Norway
}

\begin{abstract}
Farmed escapees may threaten the genetic integrity of native salmon populations through interbreeding. However, introgression requires survival until maturation, successful reproduction and successful early development. These traits are often compromised in domesticated animals selected for high performance in captivity. This makes it difficult to predict introgression levels in native populations. A recent study estimated genetic introgression of farmed escaped Atlantic salmon Salmo salar in 20 Norwegian rivers and found highly population-specific levels of introgression. The underlying causes of these patterns, however, remain unknown. Here, using a modeling approach on empirical and demographic data, we demonstrated that a combination of the observed relative frequency of escaped farmed salmon and the average annual angling catch weights for rivers, provides a significantly better predictor for cumulative introgression of farmed salmon in wild populations than the frequency of farmed salmon alone. Our results suggest that the demography of the native population is a significant factor influencing the relative success of farmed salmon in the wild.
\end{abstract}

KEY WORDS: Farmed escapees · Genetics · Introgression - Atlantic salmon · Statistical modelling · Hybridization

\section{INTRODUCTION}

Each year, 1000s or 100s of thousands of farmed Atlantic salmon Salmo salar L. escape from aquaculture installations into the wild. While the majority of escapees disappear (Hansen 2006, Skilbrei 2010a,b), presumably due to predation and starvation, some migrate into rivers where native populations spawn in regions where aquaculture activities and native populations overlap, such as Norway (Gausen \& Moen 1991, Fiske et al. 2006), UK and Ireland (Youngson et al. 1997, Walker et al. 2006), and North America (Morris et al. 2008).

Farmed salmon have undergone domestication and directional selection for $>10$ generations, and show considerable genetic differences to wild sal-

\footnotetext{
*Corresponding author: mikko.heino@uib.no
}

mon for a number of fitness-related traits. For example, they out-grow wild salmon under hatchery conditions (Glover et al. 2009, Solberg et al. 2013a,b). Wild salmon populations are regarded as potentially adapted to their natal rivers (Garcia de Leaniz et al. 2007, Fraser et al. 2011), and the survival of farmed salmon offspring in the wild is lower than for native salmon (McGinnity et al. 1997, 2003, Fleming et al. 2000, Skaala et al. 2012). Therefore, farmed escapees, and potential genetic interactions with wild conspecifics, represent a threat to the viability of native populations.

Escapees have been observed spawning with wild salmon (Lura \& Sægrov 1991, Webb et al. 1993, Sægrov et al. 1997), but experiments suggest that their spawning success, compared to wild salmon, is much

() The authors 2015. Open Access under Creative Commons by Attribution Licence. Use, distribution and reproduction are unrestricted. Authors and original publication must be credited. 
lower (Fleming et al. 1996, 2000). Nevertheless, genetic changes implying successful spawning of farmed salmon have been observed in wild populations in Norway (Skaala et al. 2006, Glover et al. 2012, 2013), Ireland (Crozier 1993, Clifford et al. 1998a,b) and Canada (Bourret et al. 2011). In the most comprehensive of these studies (Glover et al. 2013), the cumulative genetic introgression of farmed salmon over a period of 2 to 4 decades was estimated in 20 rivers spanning the entire Norwegian coastline. This was achieved through the analysis of a set of single nucleotide polymorphisms (SNPs) that collectively are diagnostic between wild and farmed Atlantic salmon (Karlsson et al. 2011). Estimated introgression ranged from 2 to $47 \%$ in the 20 rivers. However, the weighted mean frequency of farmed salmon (relative frequency of farmed salmon in the rivers combining data from summer and autumn) over the period of study (Diserud et al. 2012) left the major part of variation in estimated genetic introgression unexplained. Therefore, other variables, in addition to relative frequency of escapees, may be important for explaining the divergent pattern of introgression among rivers. Glover et al. (2013) suggested that the density of the native population, through competition on the spawning grounds, may modify the potential for introgression.

Here, we performed a statistical analysis of various population and river-specific factors, together with the estimated levels of cumulative introgression from the SNP-based study of introgression in 20 Norwegian rivers (Glover et al. 2013), in order to try to understand the divergent patterns of genetic introgression of escaped farmed salmon in natural populations. Secondly, we used statistical modelling to investigate levels of cumulative introgression in a wider set of rivers.

\section{MATERIALS AND METHODS}

\section{Data sources}

In order to form the basis of the modeling in the present study, we used the percentage of cumulative introgression of farmed salmon in 20 native rivers estimated by Glover et al. (2013) using genetic data (Table 3 in Glover et al. 2013). We obtained data on the following potential explanatory factors: relative frequency of farmed salmon in the population in 1989-2009 (Diserud et al. 2012), average weight of individual fish in the catch in 1989-2009, average annual total catch weight in 1989-2009 (for the years with non-zero catch; Anonymous 2014a), and total habitat area (Anonymous 2014b). Angling catch can serve as a proxy of current population size (although not without caveats, see Branch et al. 2011); this variable was log-transformed for the analysis. In addition to wild salmon, catches include an unknown proportion of escaped farmed salmon. Habitat area was not used directly but was used to derive a proxy related to density of spawners: catch per area is defined as the ratio between average annual total catch weight and the habitat area; this variable was square root transformed for the analysis.

\section{Statistical analysis}

The data analysis consisted of 2 steps. First, we identified the best model to explain the variability in the percentage of introgression in the 20 rivers analyzed by Glover et al. (2013). Second, we used the best model to predict introgression in a set of 99 Norwegian salmon rivers.

Because the response variable, percentage of introgression, is a real-valued variable bounded to the interval 0-100\%, we used beta regression (Ferrari \& Cribari-Neto 2004, Cribari-Neto \& Zeileis 2010) with a logit link function. We considered all possible model combinations resulting from our 4 explanatory variables, resulting in 16 candidate models. We ranked the models according to the small-sample version of Akaike's Information Criterion $\left(\mathrm{AIC}_{\mathrm{c} i}\right.$ Burnham \& Anderson 2002). The top-ranking model based on AIC was used to predict the percentage of introgression in a larger dataset of 99 rivers both with and without prediction error. Prediction error was included by bootstrapping the residuals of the model used in the prediction. All analyses were conducted with $\mathrm{R}$ 3.1.1 (R Core Team 2014).

\section{RESULTS}

No single model emerges as clearly superior in explaining the percentage of introgression in 20 rivers analyzed by Glover et al. (2013). Three models have substantial empirical support $\left(\Delta \mathrm{AIC}_{\mathrm{C}}<2\right)$; these models include either catch weight or the relative frequency of escaped farmed salmon in the spawning population as the explanatory variable, or both, the last one also being the top-ranking model (Table 1). In terms of likelihood ratio testing, the top-ranking model (\%Introgression \%Escaped + Catch weight) is significantly better than the next best one (\%Intro- 
Table 1. Eight best models (out of 16 considered models), ranked by the Akaike's Information Criterion corrected for small sample size $\left(\mathrm{AIC}_{\mathrm{c}}\right)$ for explaining the percentage of introgression in 20 rivers analyzed by Glover et al. (2013). $\Delta \mathrm{AIC}_{\mathrm{c}, i}$ is AIC difference between model $i$ and the best model and $w_{i}$ is the Akaike weight of model $i$. Akaike weights indicate the relative weight of evidence that a particular models is the best one; the remaining 8 models have a total Akaike weight of 0.03 . Pseudo- $\mathrm{R}^{2}$ describes the variability explained by the model. \%Escaped = observed frequency of escaped farmed salmon (Diserud et al. 2012); CatchWeight = average annual catch weight; CatchPerArea = catch per area, defined as CatchWeight per total habitat area; Weight $=$ mean weight of captured fish

\begin{tabular}{|llccc|}
\hline $\begin{array}{l}\text { Model } \\
\text { rank }\end{array}$ & Explanatory variable(s) & $\Delta \mathrm{AIC}_{\mathrm{c}, i}$ & $w_{i}$ & Pseudo-R \\
\hline 1 & \%Escaped + CatchWeight & 0 & 0.393 & 0.51 \\
2 & CatchWeight & 0.66 & 0.282 & 0.41 \\
3 & \%Escaped & 1.97 & 0.147 & 0.33 \\
4 & \%Escaped + CatchWeight + CatchPerArea & 4.41 & 0.043 & 0.51 \\
5 & \%Escaped + CatchWeight + Weight & 5.19 & 0.029 & 0.51 \\
6 & CatchWeight + Weight & 5.33 & 0.027 & 0.42 \\
7 & CatchWeight + CatchPerArea & 5.42 & 0.026 & 0.42 \\
8 & \%Escaped + Weight & 6.21 & 0.018 & 0.33 \\
\hline
\end{tabular}

gression $\sim$ Catch weight: $\chi^{2}=5.51, \mathrm{p}=0.019$ ) and the third best model (\%Introgression \%Escaped: $\chi^{2}=$ $6.82, \mathrm{p}=0.009$ ).

The best model (Table 1) explains $51 \%$ of the variability in the data and contains a positive effect of the relative frequency of farmed escaped salmon (coefficient for normalized variable: $0.303, \mathrm{SE}=0.114, \mathrm{p}=$ 0.008 ) and a negative effect of catch weight (coefficient for normalized variable: $-0.474, \mathrm{SE}=0.147, \mathrm{p}=$ 0.001). Thus, the effect of catch weight is quantitatively stronger than that of the relative frequency of escaped farmed salmon. Also in isolation, catch weight is a better predictor of introgression than the relative frequency of escaped farmed salmon: the model with only catch weight explains $41 \%$ of variability in the data, whereas the model with only the relative frequency of escaped farmed salmon explains $33 \%$ of variability. Moreover, the predictive power of catch weight is less sensitive to the most influential observation in the data, the river with the highest frequency of escapees (Fig. 1): dropping this observation reduces the explanatory power of the model with catch weight to $33 \%$, but that of the model with the relative frequency of escaped farmed salmon to $11 \%$.

We used the best model (Table 1) to predict the percentage of introgression in 99 Norwegian rivers where the relative frequency of farmed salmon and catch weights are available. In comparison to the relative frequency of farmed escaped salmon (Fig. 1b), fewer rivers appear to be either very heavily or very lightly impacted (Fig. 1c). For example, 42 and 5 rivers have frequencies of escaped farmed salmon $<10 \%$ or $\geq 50 \%$, respectively. However, only 24 rivers are pre- dicted to have introgression $<10 \%$; introgression $\geq 50 \%$ is predicted for 1 river only. However, if we account for prediction error (Fig. 1d), then 32 rivers are predicted to have introgression $<10 \%$ and 9 rivers are predicted to have introgression $\geq 50 \%$. The observed frequency of escaped farmed salmon (median $12 \%$, mean $16.4 \%$ ) is somewhat lower than the predicted introgression without (median $15.8 \%$, mean $17.5 \%)$ or with prediction error (median 16.2\%, mean $21.8 \%$ ).

\section{DISCUSSION}

Here, we demonstrate that a combination of the observed relative frequency of escaped farmed salmon, together with the average annual angling catch weights for rivers, provides a significantly better predictor for cumulative introgression of farmed salmon in wild populations than when using just the observed relative frequency of farmed salmon alone, or when using various combinations of the other demographic factors investigated (Table 1). Our results therefore suggest that factors other than the presence of farmed salmon in rivers also play significant roles in determining cumulative introgression of farmed salmon into wild populations.

Glover et al. (2013) suggested that the density of the native population may influence the relative success of escaped farmed salmon, and thus their ability to successfully introgress in native populations. This could be mediated through competition on the spawning grounds (Fleming et al. 1996, 2000), as well as juvenile competition in the river (McGinnity et al. 1997, 2003, Fleming et al. 2000, Skaala et al. 2012). In our analysis, none of the models with substantial empirical support included our proxy of salmon density, i.e. catch per area. Instead, we found that the average annual angling catch weights for rivers is a good explanatory variable. Remarkably, it is even a better explanatory variable than the observed relative frequency of farmed salmon, regardless of whether these 2 variables are analyzed together or separately.

Clearly, annual angling catch weight must act as a proxy of some important factor, rather than being important in its own right. Average angling catch weights over several years can be regarded as a 


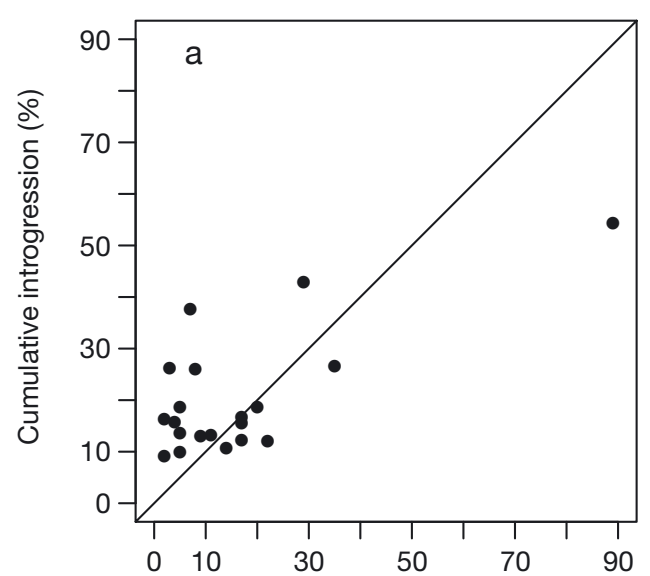

Frequency of escaped farmed salmon (\%)
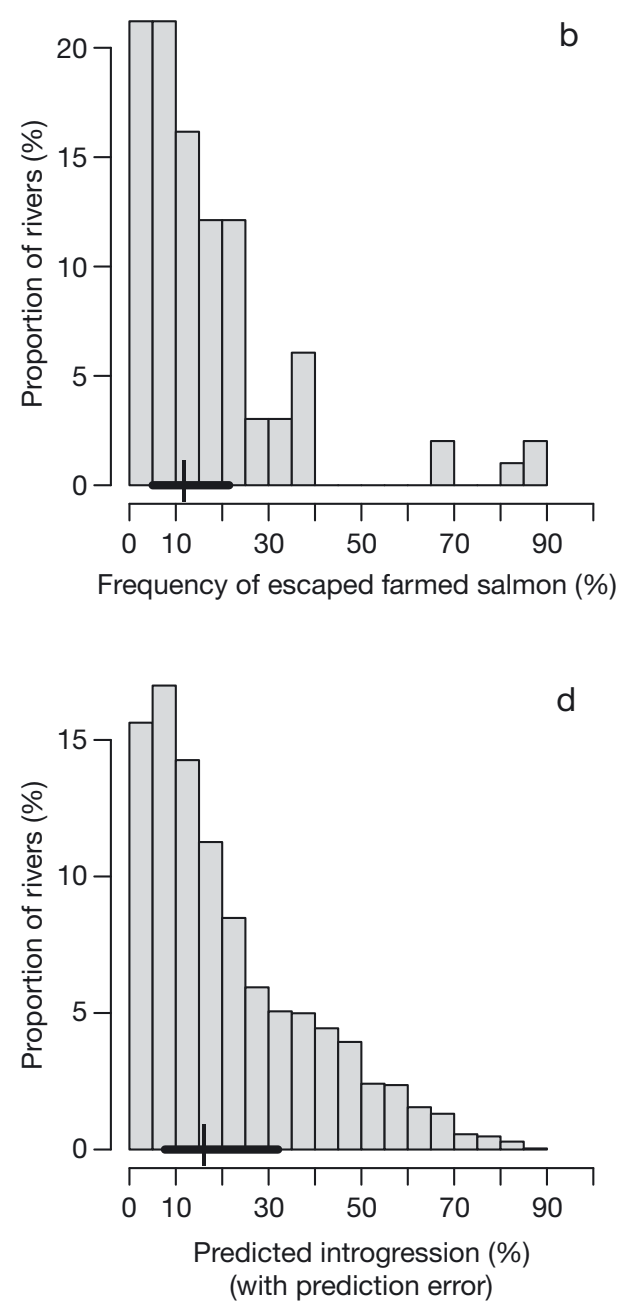

Fig. 1. (a) Relationship between the relative frequency of farmed Atlantic salmon Salmo salar (Diserud et al. 2012) and percentage of introgression measured with genetic methods in 20 Norwegian salmon rivers by Glover et al. (2013). (b) Relative frequency of farmed salmon for 99 Norwegian salmon rivers (expressed as proportion of rivers affected) (Diserud et al. 2012). (c) Predicted percentage of introgression based on average annual catch weight and the relative frequency of farmed salmon for 99 Norwegian salmon rivers. (d) As (c), but including prediction error. In (b)-(d), the thick horizontal bar gives interquartile range and the short vertical bar the median of distribution

proxy of population size, although not necessarily a good one (Branch et al. 2011). However, it is not clear why large populations should be less sensitive to introgression than small ones, given a certain proportion of farmed salmon present in a river. Average angling catch may also serve as a proxy of population status or density, assuming that healthy populations provide large catches. However, angling catch is only weakly correlated with our proxy of density, and this proxy did not perform well in the analysis. Of course, the proxy of density we have used might simply be a poor indicator of 'true' densities of spawners or early life-history stages; it is catch-based and as such inherits the weakness of catch as a proxy of population size. Thus, our results do not necessarily refute the density hypothesis. An alternative explanation for the importance of angling catch weights reverses the causal direction: it is possible that rivers with high levels of introgression become less productive, and hence, provide lower catches. We have no data, however, to support this suggestion.

Even though the observed relative frequency of escaped farmed salmon is a relatively poor predictor of cumulative introgression at the level of single rivers, it serves as a relatively good proxy of overall introgression. Using our best model to predict cumulative introgression in a larger set of rivers, we find an overall level of introgression (Fig. 1c,d) that is only slightly higher than the observed frequency of escaped farmed salmon (Fig. 1b). 
In summary, the results of the present study are based upon empirical data of introgression in 20 salmon rivers. In order to try to explain the observed patterns of cumulative introgression, only 4 potential explanatory demographic variables, and combinations therein, were evaluated. Nevertheless, the established model was still able to explain $51 \%$ of the variation in the patterns of introgression observed in the 20 rivers (Glover et al. 2013). One of the weaknesses of the present study is that a direct estimate of population density was not available. Instead, we only had a proxy of population density, which did not emerge as important in our analysis. Instead, the average angling catch emerged as important. In general, our results point to the importance of demographic processes that happen in the spawning grounds and nursery habitat, i.e. spawning success and survival of the offspring in a competitive environment, but leave the actual mechanisms open. In order to address this, modeling with larger data sets and more demographic data (in particular, density and components of productivity) will be required. Not only will this increase our understanding of the underlying mechanisms that influence the success of farmed escaped salmon in the wild, but it is also essential for sound, science-based policy.

Acknowledgements. We thank 3 reviewers for helpful comments. This study was financed by the Norwegian Ministry of Trade, Industry and Fisheries.

\section{LITERATURE CITED}

Anonymous (2014a) Lakseregister (Salmon register). Norwegian Environment Agency, Trondheim. Available at http://lakseregister.fylkesmannen.no/lakseregister/public/ default.aspx (accessed January 2014)

Anonymous (2014b) Status for Norske laksebestander i 2014. Rapport fra Vitenskapelig råd for lakseforvaltning Nr. 6, Trondheim

Bourret V, O'Reilly PT, Carr JW, Berg PR, Bernatchez L (2011) Temporal change in genetic integrity suggests loss of local adaptation in a wild Atlantic salmon (Salmo salar) population following introgression by farmed escapees. Heredity 106:500-510

Branch TA, Jensen OP, Ricard D, Ye Y, Hilborn R (2011) Contrasting global trends in marine fishery status obtained from catches and from stock assessments. Conserv Biol 25:777-786

Burnham KP, Anderson DR (2002) Model selection and multimodel inference: a practical information-theoretic approach, 2nd edn. Springer, New York, NY

> Clifford SL, McGinnity P, Ferguson A (1998a) Genetic changes in an Atlantic salmon population resulting from escaped juvenile farm salmon. J Fish Biol 52:118-127

Clifford SL, McGinnity P, Ferguson A (1998b) Genetic changes in Atlantic salmon (Salmo salar) populations of northwest Irish rivers resulting from escapes of adult farm salmon. Can J Fish Aquat Sci 55:358-363

Cribari-Neto F, Zeileis A (2010) Beta regression in R. J Stat Softw 34:1-24

Crozier WW (1993) Evidence of genetic interaction between escaped farmed salmon and wild Atlantic salmon (Salmo salar L.) in a Northern Irish river. Aquaculture 113:19-29

Diserud OH, Fiske P, Hindar K (2012) Forslag til kategorisering av laksebestander som er påvirket av rømt oppdrettslaks. NINA Rapport 782, Norwegian Institute for Nature Research, Trondheim

Ferrari S, Cribari-Neto F (2004) Beta regression for modelling rates and proportions. J Appl Stat 31:799-815

Fiske P, Lund RA, Hansen LP (2006) Relationships between the frequency of farmed Atlantic salmon, Salmo salar L., in wild salmon populations and fish farming activity in Norway, 1989-2004. ICES J Mar Sci 63:1182-1189

> Fleming IA, Jonsson B, Gross MR, Lamberg A (1996) An experimental study of the reproductive behaviour and success of farmed and wild Atlantic salmon (Salmo salar). J Appl Ecol 33:893-905

- Fleming IA, Hindar K, Mjølnerød IB, Jonsson B, Balstad T, Lamberg A (2000) Lifetime success and interactions of farm salmon invading a native population. Proc R Soc Lond B Biol Sci 267:1517-1523

Fraser DJ, Weir LK, Bernatchez L, Hansen MM, Taylor EB (2011) Extent and scale of local adaptation in salmonid fishes: review and meta-analysis. Heredity 106:404-420

Garcia de Leaniz C, Fleming IA, Einum S, Verspoor E and others (2007) A critical review of adaptive genetic variation in Atlantic salmon: implications for conservation. Biol Rev Camb Philos Soc 82:173-211

> Gausen D, Moen V (1991) Large-scale escapes of farmed Atlantic salmon (Salmo salar) into Norwegian rivers threaten natural populations. Can J Fish Aquat Sci 48: $426-428$

- Glover KA, Otterå H, Olsen RE, Slinde E, Taranger GL, Skaala Ø (2009) A comparison of farmed, wild and hybrid Atlantic salmon (Salmo salar L.) reared under farming conditions. Aquaculture 286:203-210

> Glover KA, Quintela M, Wennevik V, Besnier F, Sørvik AGE, Skaala $\varnothing$ (2012) Three decades of farmed escapees in the wild: a spatio-temporal analysis of population genetic structure throughout Norway. PLoS ONE 7: e43129

> Glover KA, Pertoldi C, Besnier F, Wennevik V, Kent M, Skaala Ø (2013) Atlantic salmon populations invaded by farmed escapees: quantifying genetic introgression with a Bayesian approach and SNPs. BMC Genet 14:74

> Hansen LP (2006) Migration and survival of farmed Atlantic salmon (Salmo salar L.) released from two Norwegian fish farms. ICES J Mar Sci 63:1211-1217

> Karlsson S, Moen T, Lien S, Glover KA, Hindar K (2011) Generic genetic differences between farmed and wild Atlantic salmon identified from a 7K SNP-chip. Mol Ecol Resour 11:247-253

> Lura H, Sæegrov H (1991) Documentation of successful spawning of escaped farmed female Atlantic salmon, Salmo salar, in Norwegian rivers. Aquaculture 98:151-159

McGinnity P, Stone C, Taggart JB, Cooke D and others (1997) Genetic impact of escaped farmed Atlantic salmon (Salmo salar L.) on native populations: use of DNA profiling to assess freshwater performance of wild, farmed, and hybrid progeny in a natural river environment. ICES J Mar Sci 54:998-1008 
McGinnity P, Prodohl P, Ferguson K, Hynes R and others (2003) Fitness reduction and potential extinction of wild populations of Atlantic salmon, Salmo salar, as a result of interactions with escaped farm salmon. Proc R Soc Lond B Biol Sci 270:2443-2450

Morris MRJ, Fraser DJ, Heggelin AJ, Whoriskey FG, Carr JW, O'Neil SF, Hutchings JA (2008) Prevalence and recurrence of escaped farmed Atlantic salmon (Salmo salar) in eastern North American rivers. Can J Fish Aquat Sci 65:2807-2826

R Core Team (2014) R: a language and environment for statistical computing. R Foundation for Statistical Computing, Vienna. www.R-project.org

Sægrov H, Hindar K, Kålås S, Lura H (1997) Escaped farmed Atlantic salmon replace the original salmon stock in the River Vosso, western Norway. ICES J Mar Sci 54: 1166-1172

Skaala Ø, Wennevik V, Glover KA (2006) Evidence of temporal genetic change in wild Atlantic salmon, Salmo salar L., populations affected by farm escapees. ICES J Mar Sci 63:1224-1233

Skaala Ø, Glover KA, Barlaup BT, Svåsand T, Besnier F, Hansen MM, Borgstrøm R (2012) Performance of farmed, hybrid, and wild Atlantic salmon (Salmo salar) families in a natural river environment. Can J Fish Aquat Sci 69: 1994-2006

Skilbrei OT (2010a) Adult recaptures of farmed Atlantic salmon post-smolts allowed to escape during summer.

Editorial responsibility: Ian Fleming,

St. John's, Newfoundland and Labrador, Canada
Aquacult Environ Interact 1:147-153

Skilbrei OT (2010b) Reduced migratory performance of farmed Atlantic salmon post-smolts from a simulated escape during autumn. Aquacult Environ Interact 1: 117-125

Solberg MF, Glover KA, Nilsen F, Skaala Ø (2013a) Does domestication cause changes in growth reaction norms? A study of farmed, wild and hybrid Atlantic salmon families exposed to environmental stress. PLoS ONE 8: e54469

Solberg MF, Zhang ZW, Nilsen F, Glover KA (2013b) Growth reaction norms of domesticated, wild and hybrid Atlantic salmon families in response to differing social and physical environments. BMC Evol Biol 13:234

> Walker AM, Beveridge MCM, Crozier W, Ó Maoiléidigh N, Milner N (2006) Monitoring the incidence of escaped farmed Atlantic salmon, Salmo salar L., in rivers and fisheries of the United Kingdom and Ireland: current progress and recommendations for future programmes. ICES J Mar Sci 63:1201-1210

Webb JH, Youngson AF, Thompson CE, Hay DW, Donaghy MJ, McLaren IS (1993) Spawning of escaped farmed Atlantic salmon, Salmo salar L., in western and northern Scottish rivers: egg deposition by females. Aquac Fish Manag 24:557-561

Youngson AF, Webb JH, MacLean JC, Whyte BM (1997) Frequency of occurrence of reared Atlantic salmon in Scottish salmon fisheries. ICES J Mar Sci 54:1216-1220

Submitted: July 7, 2014; Accepted: January 15, 2015

Proofs received from author(s): February 3, 2015 